\title{
Ontogenesis of corticotropes and lactotropes in situ in the pituitary gland of the hamster
}

\section{An immunohistochemical study}

\author{
G.T. CampbelI ${ }^{1}$, J. Wagoner ${ }^{1}$, K.T. Borer ${ }^{2}$, R.P. Kelch ${ }^{2}$, and K. Corley ${ }^{2}$ \\ ${ }^{1}$ Department of Physiology and Biophysics, University of Nebraska College of Medicine, Omaha, Nebraska, USA; \\ 2 Departments of Physical Education and Pediatrics, University of Michigan, Ann Arbor, Michigan, USA
}

\begin{abstract}
Summary. The development of corticotropes and lactotropes was investigated in the golden Syrian hamster using an anti-porcine ACTH antiserum and a homologous antihamster PRL antiserum. Oval corticotropes were first visible in the ventral region of the pars distalis at 13 days of gestation. By the end of gestation, corticotropes were found throughout the pars distalis and in the pars intermedia. Corticotropes in the pars distalis of postnatal hamsters were either round or irregularly-shaped, often appearing in clusters. Throughout development, corticotropes often appeared to be surrounding other cells. Scarce, very small lactotropes were first observed in the pars distalis of hamsters on the first postnatal day. The number of these cells, which were either round or polyhedral, increased dramatically between 4 and 20 days of postnatal life. These observations indicate that the sequence of appearance of corticotropes and lactotropes in the hamster is similar to that in other species and that lactotropes are confined to the pars distalis of postnatal hamsters.
\end{abstract}

Key words: Pituitary gland - ACTH cells - PRL cells Immunohistochemistry - Development - Mesocricetus auratus

Studies on the development of adenohypophyseal cells, particularly those of the rat, have increased since the advent of immunohistochemical (IHC) methods to identify intracellular hormones. The results of most studies indicate that corticotropes are the first to differentiate. These cells, which initially are ovoid, appear in the pars distalis of fetal rats between 14-16 days of gestation (Sétáló and Nakane 1976; Watanabe and Daikoku 1979). The typical irregularlyshaped corticotrope is recognizable towards the end of gestation (Dupouy and Dubois 1975; Sétáló and Nakane 1976; Dupouy 1977; Watanabe and Daikoku 1979).

Although the ontogenesis of lactotropes in the rat has been the focus of several investigations, controversy still exists concerning the age at which these cells first appear. Sétáló and Nakane (1976) and Chatelain et al. (1979) found PRL cells in pituitary glands of fetal rats; whereas, Watanabe and Daikoku (1979) observed them only in glands of postnatal rats. However, lactotropes have been identified

Send offprint requests to: Dr. Gary T. Campbell, Department of Physiology, University of Nebraska Medical Center, 42nd Street and Dewey Avenue, Omaha, NE 68105, USA in the pituitary glands of fetuses of other species such as the hamster (Thompson and Trimble 1976), sheep (Stokes and Boda 1968), and human (Baker and Yen 1977). Interestingly, Thompson and Trimble (1976), using an antiserum to ovine PRL, observed lactotropes in the pars tuberalis as well as pars distalis of fetal hamsters. Due to the lack of contemporary evidence that cells in the pars tuberalis of adult hamsters contain PRL, they postulated that these cells either migrated to the pars distalis or lost the capability to synthesize PRL during development. Since we have been unable to visualize lactotropes in pituitary glands of fetal hamsters using a number of antisera to rat PRL (Gregerson et al. 1980), one aim of the present study was to reinvestigate the ontogenesis of lactotropes in the hamster using an homologous antiserum to hamster PRL (Borer et al. 1982). As we have studied the cytodifferentiation of gonadotropes in the hamster (Gregerson and Campbell 1982), we also investigated the differentiation of ACTH cells to extend the description of the development of the hamster adenohypophysis.

\section{Materials and methods}

\section{Animals}

Pregnant golden Syrian hamsters (Mesocricetus auratus) were obtained from Engle Laboratories, Farmersburg, IN. Cyclic females were housed with adult males on the night of proestrus and early morning of estrus. The day following mating was considered the first day of gestation. The hamsters arrived in Omaha on the 11th day of pregnancy. We have purchased 15 such shipments of pregnant hamsters from Engle in the past and, in every case, parturition occurred on the scheduled day. For these studies, we used 45 pregnant hamsters. They were kept individually in maternity cages in a room with a daily lighting schedule of 14L:10D (lights on 0600-2000 h). The temperature ranged from $23-24^{\circ} \mathrm{C}$. Food and water were always available.

\section{Tissues used for immunohistochemistry}

Fetuses were obtained through cesarian sections with the pregnant hamsters under chloral hydrate anesthesia $(2 \mathrm{mg} /$ $100 \mathrm{~g}$ body weight). In other animals, parturition occurred during the dark period after 16 days of gestation; the following day was considered day 1 of postnatal life. Fetuses or pups were decapitated at the following ages: 13, 14, 
15 or 16 days of gestation and $1,4,7,10,14$ or 20 days postnatally.

A block of tissue, generally including the pituitary gland, surrounding connective tissue, and the sphenoid bone, was removed and placed in Bouin's fixative for $48 \mathrm{~h}$. The pars tuberalis was not always present. The sex of hamsters killed on or after 15 days of gestation was determined by visual inspection of the gonads. Two fetuses removed from each of 3 different pregnant hamsters on the 13th day of gestation were used. A total of 5 animals of each sex were taken from 3 different litters at the other ages. Only litters that contained between 7-10 pups were used to obtain postnatal tissue.

All tissues were dehydrated, stored in $75 \%$ cedar wood oil $-25 \%$ absolute ethanol, cleared in xylene, and embedded in Paraplast. Horizontal sections of the pituitary glands were cut at $5 \mu \mathrm{m}$ thickness starting from the dorsal surface. Every 20th section was mounted and stained with hematoxylin for orientation. Sections used for this study were taken from the ventral, middle, and dorsal regions of the pituitary glands.

\section{Immunohistochemical staining}

The avidin-biotin-peroxidase complex (ABC) method was used (Hsu et al. 1981; Childs and Unabia 1982). The sections were deparaffinized in xylene, rehydrated, and washed in phosphate-buffered saline (PBS). Sections were incubated sequentially with the following solutions for the times indicated: $1: 100$ normal goat serum for $1 \mathrm{~h}$, primary antiserum or normal rabbit serum (NRS) for $16 \mathrm{~h}, 1: 100$ normal goat serum for $1 \mathrm{~h}$, biotinylated-antirabbit gamma globulin for $1 \mathrm{~h}$, avidin-biotinylated peroxidase complex for $1 \mathrm{~h}$. The $\mathrm{ABC}$ reagents were purchased from and prepared as described by Vector Laboratories, Burlingame, CA. The sections were washed with PBS after all incubations. All incubations were done in a moist chamber at $24 \mathrm{C}$.

Peroxidase activity was visualized using a fresh solution of $3,3^{\prime}$-diaminobenzidine $(0.25 \mathrm{mg} / \mathrm{ml})$ in Tris (hydroxymethyl)-aminomethane buffer, $\mathrm{pH}$ 7.6. This solution was stirred for $10 \mathrm{~min}$ and then filtered. Immediately before use; enough hydrogen peroxide was added to give a final concentration of $0.003 \%$. Sections were incubated for $4 \mathrm{~min}$ in the staining solution, washed, sometimes counterstained with hematoxylin, and mounted.

The following primary antisera were used: anti-hamster PRL RK 1-15 obtained from Dr. R. Kelch (Borer et al. 1982), anti-porcine ACTH (Lot. No. 11151) purchased from Immunonuclear Corp, Stillwater, $\mathrm{MN}$ and anti-rat LH S-4 (NIADDK). Four different batches of normal rabbit serum (NRS) also were used. All antisera and the NRS were diluted with $0.01 \mathrm{M}$ PBS-EDTA.

The initial step in the IHC procedure was to ascertain the titer of the antisera using sections from each pituitary gland. The anti-hamster PRL antiserum was used at 1:500-1:40000 dilutions, the anti-porcine ACTH was used at $1: 400-1: 4000$ and the anti-rat LH at 1:100-1:2000. NRS was used at $1: 10-1: 800$.

In subsequent staining experiments with sections from the pituitary glands of 20-day-old hamsters of both sexes, the anti-porcine ACTH $(1: 800)$ was absorbed with porcine ACTH (Grade II, 85 I.U./mg; Sigma, St. Louis, MO) or human ACTH 1-39 (Bachem Inc., Torrance, CA) at concentrations of $0.001-10 \mu \mathrm{g} / \mathrm{ml}$ or with hamster PRL (Colosi et al. 1981) or rat GH (NIADDK I-4) at concentrations of 5 and $50 \mu \mathrm{g} / \mathrm{ml}$. The anti-hamster PRL $(1: 5000)$ was absorbed with each of the following: hamster PRL $(0.01-10 \mu \mathrm{g} / \mathrm{ml})$; porcine or human ACTH $(1-100 \mu \mathrm{g} / \mathrm{ml})$; rat $\mathrm{GH}(50 \mu \mathrm{g} / \mathrm{ml})$. The reactivity of anti-rat LH S-4 with various hormones has been described (Gregerson and Campbell 1982; Dada et al. 1983). Absorbed antisera were allowed to incubate with various hormones for $48 \mathrm{~h}$ at $4 \mathrm{C}$ before application to tissue sections. Unabsorbed anti-porcine ACTH, anti-hamster PRL, and anti-rat LH antisera were used in the cytodifferentiation studies.

\section{Results}

No specific staining was observed with any dilution of the batches of NRS. No overt sex differences were noted.

\section{Antisera specificities}

The staining in the pars distalis of glands removed from hamsters at 20 days of age observed with a 1:800 dilution of anti-porcine ACTH (Fig. 1 a) was abolished by prior absorption with $0.001 \mu \mathrm{g} / \mathrm{ml}$ porcine (Fig. $1 \mathrm{~b}$ ) or human ACTH or by absorption with $50 \mu \mathrm{g} / \mathrm{ml}$ hamster PRL (Fig. $1 \mathrm{c}$ ). Absorption with $50 \mu \mathrm{g} / \mathrm{ml}$ rat $\mathrm{GH}$ did not affect the staining intensity. The staining in the pars intermedia also was abolished by absorption of the anti-porcine ACTH with $0.001 \mu \mathrm{g} / \mathrm{ml}$ porcine or human ACTH or $50 \mu \mathrm{g} / \mathrm{ml}$ hamster PRL but not with rat GH.

Absorption of the anti-hamster PRL (1:5000) with $1.0 \mu \mathrm{g} / \mathrm{ml}$ hamster PRL abolished the staining in the pars distalis of pituitary glands removed from 20-day-old hamsters (Fig. 2a, b). Prior absorption of this antiserum with porcine ACTH $(100 \mu \mathrm{g} / \mathrm{ml})$, human ACTH $(100 \mu \mathrm{g} / \mathrm{ml})$, or rat $\mathrm{GH}(50 \mu \mathrm{g} / \mathrm{ml})$ had no effect on the staining intensity (Fig. 2c, d).

\section{Anti-porcine ACTH}

The anti-porcine ACTH at a 1:400 dilution allowed detection of cells in the ventral portion of the pars distalis of glands removed from hamsters on the 13th day of gestation. Many oval cells in all regions of the pars distalis of glands removed from hamsters on the 14th day of gestation were stained with a 1:800 dilution of the anti-porcine ACTH (Fig. 3a). A few cells in the pars intermedia, as well as cells in the pars distalis, of glands of hamsters killed on either 15 or 16 days of gestation were stained with this dilution of the anti-porcine (Fig. 3c). Round or irregularlyshaped cells in the pars distalis of pituitary glands removed from postnatal hamsters (days 1-20) were stained (Figs. $1 \mathrm{a}$, $5 \mathrm{a})$. The stained cells in the pars distalis often occurred in clusters and sometimes appeared to be surrounding round, unstained cells. By day 20 almost all cells in the pars intermedia were stained (Fig. 5a). The dilution of the antiserum that detected cells in the pars distalis and pars intermedia increased with advancing age of the hamster pups to reach a maximum of 1:4000 when glands from pups 20 days of postnatal age were used.

\section{Anti-hamster PRL}

No cells in any portion of pituitary glands of fetal hamsters were detected with any dilution of this antiserum (Fig. 3b). 

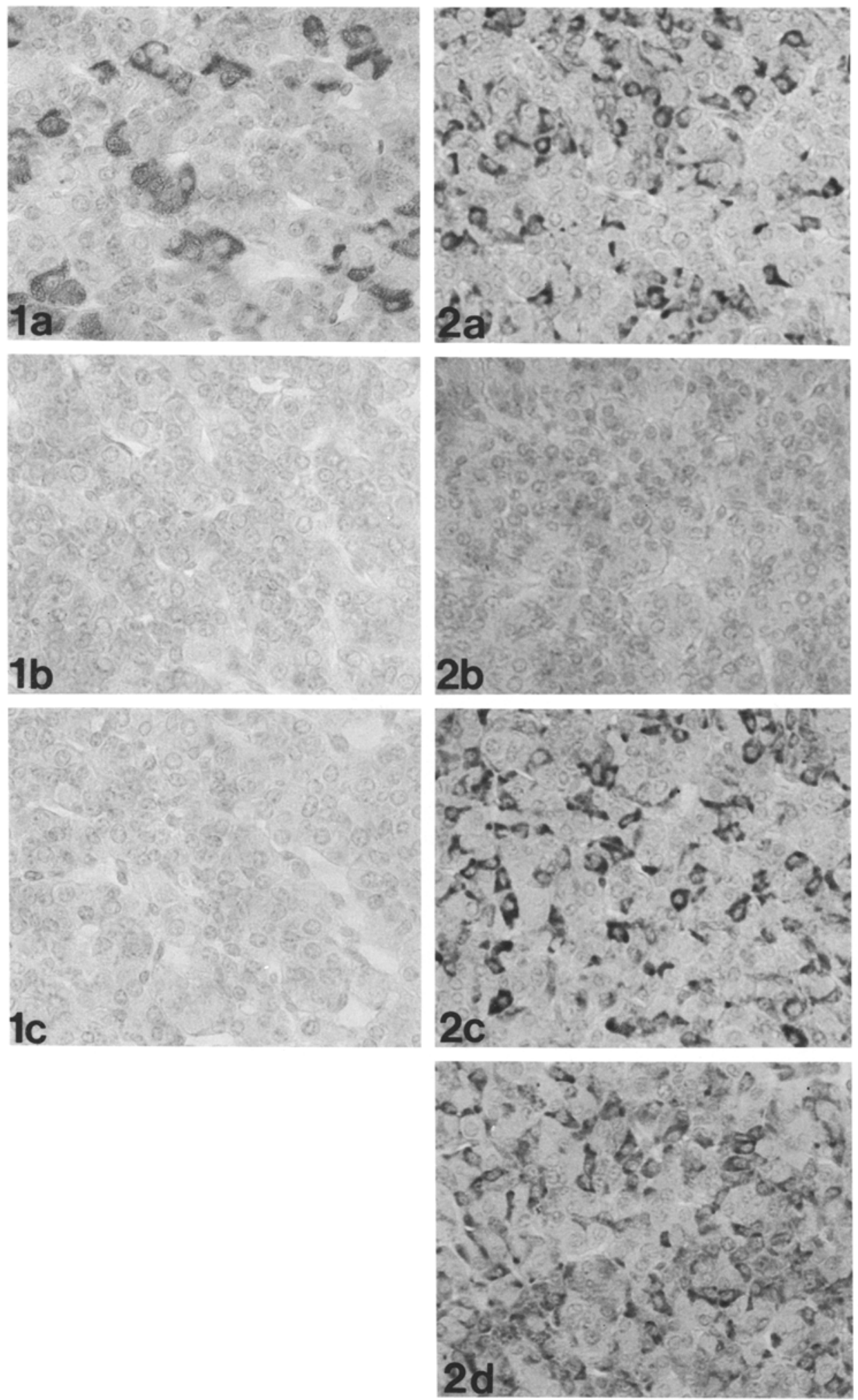

Fig. 1. a Cells immunoreactive with anti-porcine ACTH in the pars distalis of a pituitary gland removed from a female hamster at 20 days of age. $b$ Abolition of staining after absorption of antiporcine ACTH with porcine ACTH $(0.001 \mu \mathrm{g} / \mathrm{ml}$ antiserum). c Abolition of staining after absorption of anti-porcine ACTH with hamster PRL $(50 \mu \mathrm{g} / \mathrm{ml}$ antiserum). Magnification for $a-c$ $\times 325$

Fig. 2. a Cells immunoreactive with anti-hamster PRL in the pars distalis of a pituitary gland removed from a female hamster at 20 days of age. $\mathbf{b}$ Abolition of the staining after absorption of antihamster PRL with hamster PRL $(1.0 \mu \mathrm{g} / \mathrm{ml}$ antiserum). c Absence of affect of absorption of the antihamster PRL with porcine ACTH $(100 \mu \mathrm{g} / \mathrm{ml}$ antiserum). d Absence of affect of absorption of the antihamster PRL with rat $\mathrm{GH}$ $(50 \mu \mathrm{g} / \mathrm{ml}$ antiserum $)$. Magnification for $\mathrm{a}-\mathrm{d} \times 325$
A few very lightly-stained cells scattered throughout the pars distalis were detected in pituitary glands of hamsters of 1 day of postnatal age (Fig. 4 a). The number of small cells, which were either oval or irregularly-shaped, located in all regions of the pars distalis increased throughout development of the hamsters (Figs. 2a, 5b). Some of these cells formed cup-like arrangements around unstained cells. The maximal dilution of this antiserum that allowed visualiza- tion of these cells increased to $1: 40000$ when pituitary glands from hamsters 20 days of age were used. This antiserum detected cells only in the pars distalis of the glands.

\section{Anti-rat $L H$}

This antiserum was used to determine if gonadotropes could be found in the pars tuberalis. Cells in the pars tuberalis 
and pars distalis were stained with the anti-rat LH S-4 (Fig. 4b) but not with either anti-hamster PRL (Fig. 4a) or anti-porcine ACTH.

\section{Discussion}

\section{Specificities of antisera}

The objective of these studies was to describe the sequence of cytodifferentiation of corticotropes and lactotropes in situ in the pituitary gland of the hamster. The ultimate resolution of this question resides in the elucidation of the specificities of the antisera used in the IHC studies. Approximately $5 \times 10^{4}$ times more hamster PRL than porcine $\mathrm{ACTH}$ was needed to abolish the staining obtained with the anti-porcine ACTH. This small amount of cross-reactivity could be due to either unspecific interactions between the anti-porcine ACTH and hamster PRL or a small degree of contamination of the hamster PRL with big ACTH which has been reported to exist in rats (Loh and Gainer 1982). Absorption of the antiporcine ACTH with rat $\mathrm{GH}$ failed to affect the staining. Because of the low amount of cross-reactivity of the anti-porcine ACTH with hamster PRL or various rat hormones (Dada et al. 1984), we think that we can define the cells identified with the anti-porcine $\mathrm{ACTH}$ as hamster corticotropes.

We think that the anti-hamster PRL was reacting exclusively with hamster PRL for the following reasons: (a) No displacement was observed in the radioimmunoassay for hamster PRL using this antiserum when rat GH, LH or FSH were tested and only minimal displacement was found when hamster $\mathrm{GH}$ was added to the assay system (Borer et al. 1982). (b) We have found that addition of porcine or human ACTH does not affect the radioimmunoassay for hamster PRL (unpublished observation). However, it should be pointed out that radioimmunoassay systems can not be used as the sole method for detection of cross-reactivity of antisera to be used in immunohistochemistry (Larsson 1981; Larsson and Rehfeld 1977). (c) In the present IHC studies the staining obtained with the antiserum was abolished by absorption with a preparation of hamster PRL, which did not serve as the immunogen for generation of the antiserum, but was not abolished by absorption with any of the other hormones tested. (d) The anti-hamster PRL did not stain cells in the pituitary glands of fetal hamsters; whereas, the anti-porcine ACTH did. (e) The cells in pituitary glands of postnatal hamsters that were stained resembled those described as lactotropes in other species (Nakane 1970; Merchant 1974; Girod and Dubois 1976; Baker and Yen 1977).

\section{Ontogenesis of corticotropes}

The sequence of development of corticotropes in the hamster is similar to the ontogenesis of corticotropes in the rat. Oval corticotropes were first demonstrated in the ventral part of the pars distalis of hamsters on the 13th day of gestation. Similar cells have been reported to appear in the pars distalis of fetal rats between 14 and 16 days of gestation (Sétáló and Nakane 1976; Watanabe and Daikoku 1979). Although numerous authors have suggested a close relationship between ventral mesenchymal tissue and differentiation of ACTH cells (Bugnon et al. 1974; Baker and Jaffe 1975; Watanabe and Daikoku 1979), it has also
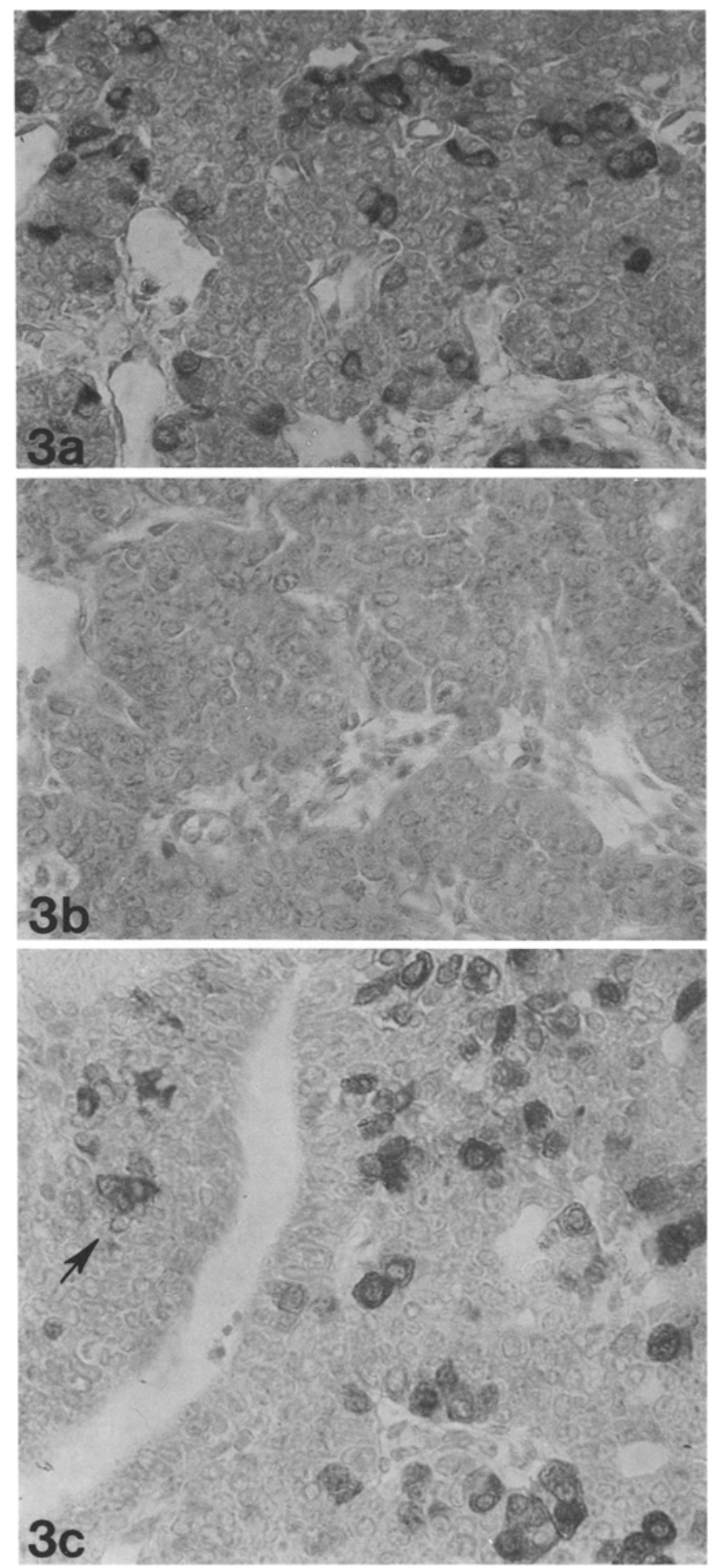

Fig. 3. a Cells immunoreactive with anti-porcine ACTH in the pars distalis of a pituitary gland removed from a hamster at 14 days of gestation. Magnification $\times 325$. b Absence of cells immunoreactive with the anti-hamster PRL in a section $10 \mu \mathrm{m}$ removed from the section illustrated in Fig. 3a. Magnification $\times 325$. c Cells immunoreactive with anti-porcine $\mathrm{ACTH}$ in the pars distalis and pars intermedia (arrow) of a pituitary gland removed from a female hamster at 15 days of gestation. Magnification $\times 325$

been reported that $\mathrm{ACTH}$ cells begin differentiation in the dorsal region in close proximity to the diencephalic floor and that the ventral localization by immunohistochemistry is due to migration of the cells and accumulation of intracel- 

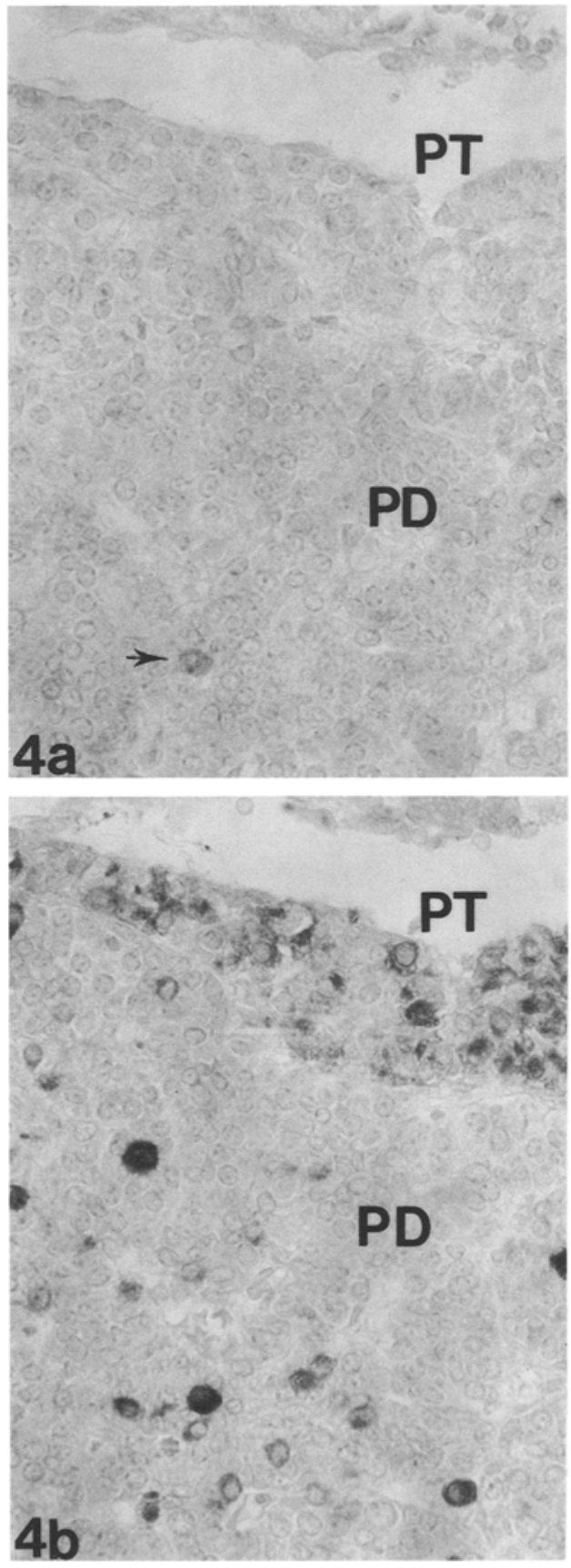
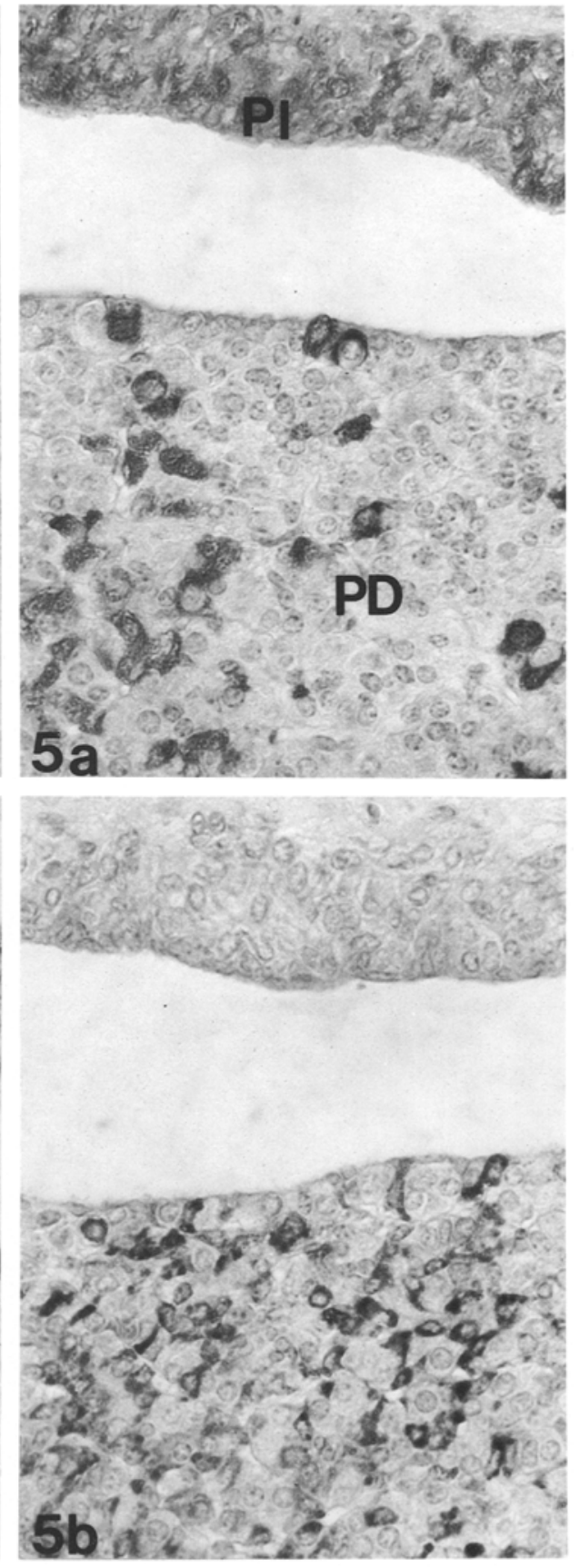

Fig. 4. a A cell immunoreactive with the anti-hamster PRL in the pars distalis of a pituitary gland removed from a female hamster at 1 day of postnatal life (arrow). b Cells immunoreactive with the anti-rat $\mathrm{LH}$ in the pars distalis $(P D)$ and pars tuberalis $(P T)$ of the same pituitary gland. The sections illustrated in Figs. 4a and $\mathbf{4 b}$ are $10 \mu \mathrm{m}$ apart.

Magnification $\mathrm{a}, \mathrm{b} \times 325$

Fig. 5. a Cells immunoreactive with the anti-porcine $\mathrm{ACTH}$ in the pars intermedia $(P I)$ and pars distalis $(P D)$ of a pituitary gland removed from a female hamster 20 days old.

b Cells immunoreactive with the anti-hamster in the serial section. Magnification $\mathrm{a}, \mathrm{b} \times 325$ lular ACTH (Watanabe 1982). By day 15 of gestation in the hamster, these oval corticotropes were distributed throughout the pars distalis and corticotropes began to appear in the pars intermedia. Transformation of the oval corticotropes into the "stellate" cell occurs toward the end of gestation in the rat (Dupouy and Dubois 1975; Sétáló and Nakane 1976; Dupouy 1977; Watanabe and Daikaku 1979); whereas, the type of corticotrope appearing in the pars distalis of older postnatal hamsters, the large, oval or irregularly-shaped cell often found in clusters, did not appear until after several days of postnatal life.

These corticotropes in the pars distalis of 20-day-old hamsters resembled, in the following ways, the corticotropes observed in adult rats: (a) They were distributed throughout the pars distalis except that they were sparse alongside the border of the residual lumen (Baker et al. 1970). (b) They often appeared to be engulfing other cells. A cytoarchitectural arrangement between corticotropes and somatotropes has been reported to exist in the adult rat (Siperstein and Miller 1970; Nakane 1970). In the hamster, corticotropes could be found engulfing other cells throughout development.

The appearance of ACTH in the pars intermedia of the hamster was not surprising since ACTH exists in the pars intermedia of other species (Halmi and Krieger 1983). In the hamster, as in the rat (Dupouy and Dubois 1975) corticotropes appeared in the pars distalis before they appeared in the pars intermedia and not all cells in the pars intermedia acquired immunoreactive ACTH at the same time during development. 


\section{Ontogenesis of lactotropes}

One objective of these studies was to determine the age at which lactotropes appeared in the different portions of the hamster pituitary gland. We think our data mean that the small cells, which were either oval or polyhedral, detected in the pars distalis of pituitary glands of postnatal hamsters, are lactotropes. Although these cells morphologically resemble those that have been classified as lactotropes in other species (Baker and Yen 1977; Nakane 1970; Girod and Dubois 1976; Merchant 1974), it should be pointed out that some authors have described larger PRL cells (Merchant 1974; Girod and Dubois 1976; Baker and Yen 1977).

The visualization of lactotropes in the pars distalis of glands of postnatal hamsters with the anti-hamster PRL agrees with our previous findings using numerous antisera directed against rat PRL (Gregerson et al. 1980), but conflicts with the report of Thompson and Trimble (1976) who found cells in the pars distalis as early as $13^{1 / 2}$ days of gestation and cells in the pars tuberalis at $15^{1 / 2}$ days of gestation which were immunoreactive with an antiserum generated against ovine PRL. Cross-reactivity of their antiovine PRL with ACTH would account for the following: (a) detection of cells in the pars distalis of fetal hamsters; (b) detection of a substantial population of large, rounded cells in the pars distalis of hamsters killed at $1 / 2-3^{1 / 2}$ days of postnatal life; and (c) visualization of immunoreactive cells in the pars intermedia of postnatal hamsters (Figs. 912, Thompson and Trimble 1976). Although we have not studied it extensively, the only cell type that we have been able to visualize as yet in the pars tuberalis has been the gonadotrope.

The postnatal development of lactotropes was characterized by: (a) an absence of a sex difference; (b) an increase in the number of cells throughout postnatal life; (c) a uniform distribution of cells throughout the pars distalis; and, (d) a cytoarchitectural arrangement between lactotropes and other cells that resembled gonadotropes. Such an arrangement has been described in the rat (Nakane 1970; Sato 1980).

In summary, based on studies done to date, the cytodifferentiation of the hamster pituitary gland, in which the appearance of corticotropes precedes the appearance of gonadotropes (Gregerson and Campbell 1982), which precedes the development of lactotropes, resembles the cytodifferentiation of the rat hypophysis.

Acknowledgments. We wish to express our sincere thanks to Denise Raemsch, Sharon Clawson, and Martin Wolf for technical assistance and Ruth D. Cozette for secretarial assistance and The Hormone Distribution Officer, NIADDK, Bethesda, MD, for providing rat hormones and antisera. This investigation was supported by grant NIH AM 19170.

\section{References}

Baker BL, Jaffe RB (1975) The genesis of cell types in the adenohypophysis of the human fetus as observed with immunocytochemistry. Am J Anat 143:137-162

Baker BL, Yen YY (1977) An immunocytochemical study of human pituitary mammotropes from fetal life to old age. Am J Anat 148:217-240

Baker BL, Pek S, Midgley Jr AR, Gersten BE (1970) Identification of the corticotropin cell in rat hypophyses with peroxidaselabeled antibody. Anat Rec 164:557-567
Begeot M, Dubois MP, Dubois PM (1977) Growth hormone and ACTH in the pituitary of normal and anencephalic human fetuses: immunocytochemical evidence for hypothalamic influence during development. Neuroendocrinology 24:208-220

Borer KT, Kelch RP, Corley K (1982) Hamster prolactin: physiological changes in blood and pituitary concentrations as measured by a homologous radioimmunoassay. Neuroendocrino$\operatorname{logy} 35: 13-21$

Bugnon C, Lenys D, Bloch B, Fellman D (1974) Etude cyto-immunochimique des phénomènes de différenciation cellulaire précoce dans l'adénohypophyse foetale humaine. CR Soc Biol 168:460-465

Chatelain A, Dupouy JP, Dubois MP (1979) Ontogenesis of cells producing polypeptide hormones (ACTH, MSH, LPH, GH, Prolactin) in the fetal hypophysis of the rat: influence of the hypothalamus. Cell Tissue Res 196:406-427

Childs (Moriarty) G, Unabia G (1982) Application of the avidinbiotin-peroxidase complex (ABC) method to the light microscopic localization of pituitary hormones. J Histochem Cytochem 30:713-716

Colosi P, Markoff E, Levy A, Ogren L, Shine N, Talamantes F (1981) Isolation and partial characterization of secreted hamster pituitary prolactin. Endocrinology 108:850-854

Dada MO, Campbell GT, Blake CA (1983) A quantitative immunocytochemical study of the luteinizing hormone and follicle-stimulating hormone cells in the adenohypophysis of adult male rats and adult female rats throughout the estrous cycle. Endocrinology 113:970-984

Dada MO, Campbell GT, Blake CA (1984) Pars distalis cell quantitation in normal adult male and female rats. $J$ Endocrinol $101: 87-95$

Dupouy JP (1977) CRF activity in fetal rat hypothalamus in late pregnancy. Neuroendocrinology 19:303-313

Dupouy JP, Dubois MP (1975) Ontogenesis of the $\alpha$-MSH, $\beta$-MSH and ACTH cells in the foetal hypophysis of the rat. Correlation with the growth of the adrenals and adrenocortical activity. Cell Tissue Res 161:373-384

Girod C, Dubois MP (1976) Immunofluorescent identification of somatotropic and prolactin cells in the anterior lobe of the hypophysis (pars distalis) of the monkey, Macacus irus. Cell Tissue Res 172:145-148

Gregerson KA, Campbell GT (1982) Influences of luteinizing hormone releasing hormone, hypophysectomy and orchidectomy on the differentiation of luteinizing hormone and follicle stimulating hormone cells in an ectopic pituitary in the hamster. Biol Reprod 27:169-181

Gregerson KA, Wagoner J, Campbell GT (1980) Differentiation of lactotrophs and gonadotrophs in the hamster. Fed Proc $39: 488$

Halmi NS, Krieger D (1983) Immunocytochemistry of ACTH-related peptides in the hypophysis. In: Bhatnagar AS (ed) The anterior pituitary gland. Raven Press, New York, pp 1-15

Hsu S-M, Raine L, Fanger H (1981) Use of avidin-biotin-peroxidase complex $(\mathrm{ABC})$ in immunoperoxidase techniques. A comparison between $\mathrm{ABC}$ and unlabeled antibody (PAP) procedures. J Histochem Cytochem 29:577-580

Larsson LI (1981) A novel immunocytochemical model system for specificity and sensitivity screening of antisera against multiple antigens. J Histochem Cytochem 29:408-410

Larsson LI, Rehfeld JF (1977) Characterization of antral gastrin cells with region-specific antisera. J Histochem Cytochem 25:1317-1321

Li JY, Dubois MP, Dubois PM (1977) Somatotrophs in the human fetal anterior pituitary. An electron microscopic-immunocytochemical study. Cell Tissue Res 181:545-552

Loh YP, Gainer H (1982) Characterization of pro-opiocortin-converting activity in purified secretory granules from rat pituitary neurointermediate lobe. Proc Natl Acad Sci USA 79:108-112

Merchant FW (1974) Prolactin and luteinizing hormone cells of pregnant and lactating rats as studied by immunohistochemistry and radioimmunoassay. Am J Anat 139:245-268 
Nakane PK (1970) Classifications of anterior pituitary cell types with immunoenzyme histochemistry. J Histochem Cytochem $18: 9-20$

Sato S (1980) Postnatal development, sexual difference and sexual cyclic variation of prolactin cells in rats: special reference to the topographic affinity to a gonadotroph. Endocrinol Japon 27:573-583

Sétáló G, Nakane PK (1976) Functional differentiation of the fetal anterior pituitary cells in the rat. Endocrinol Exp 10:155-166

Siperstein ER, Miller KJ (1970) Further cytophysiologic evidence for the identity of the cells that produce adrenocorticotrophic hormone Endocrinology 86:451-486

Stokes H, Boda JM (1968) Immunofluorescent localization of growth hormone and prolactin in the adenohypophysis of fetal sheep. Endocrinology 83:1362-1366
Thompson SA, Trimble JJ (1976) Immunohistochemical localization of prolactin cells of the pars distalis in the fetal and neonatal hamster. A light and electron microscopy study. Cell Tissue Res 168:161-175

WatanabeYG (1982) An organ culture study on the site of determination of ACTH and LH cells in the rat adenohypophysis. Cell Tissue Res 227:267-275

Watanabe YG, Daikoku S (1979) An immunohistochemical study on the cytogenesis of adenohypophysial cells in fetal rats. Dev Biol 68:557-567

Accepted April 2, 1986 